\title{
Editorial: Phosphorus Along the Soil-Freshwater-Ocean Continuum
}

\author{
Barbara J. Cade-Menun ${ }^{1 *}$, Solange Duhamel ${ }^{2}$, Rosalind J. Dodd ${ }^{3}$, Christian Lønborg ${ }^{4}$, \\ Chris T. Parsons ${ }^{5}$ and William D. Taylor ${ }^{6}$ \\ ${ }^{1}$ Agriculture and Agri-Food Canada, Swift Current Research and Development Centre, Swift Current, SK, Canada, ${ }^{2}$ Lamont \\ Doherty Earth Observatory, Division of Biology and Paleo Environment, Columbia University, Palisades, NY, United States, \\ ${ }^{3}$ Faculty of Agriculture and Life Sciences, Lincoln University, Lincoln, New Zealand, ${ }^{4}$ Australian Institute of Marine Science, \\ Townsville, QLD, Australia, ${ }^{5}$ Department of Earth and Environmental Sciences and the Water Institute, University of Waterloo, \\ Waterloo, ON, Canada, ${ }^{6}$ Department of Biology, University of Waterloo, Waterloo, ON, Canada
}

Keywords: phosphorus, land-water continuum, lakes, estuaries, oceans, soil

Editorial on the Research Topic

\section{Phosphorus Along the Soil-Freshwater-Ocean Continuum}

Phosphorus (P) is an essential element for all organisms. However, there is a $\mathrm{P}$ paradox, whereby $\mathrm{P}$ concentrations considered deficient in some environments such as in agricultural soils are considered excessive in freshwater, where they trigger eutrophication (e.g., Sims and Sharpley, 2005 and references therein; Elser and Bennet, 2011; Lougheed, 2011). Geographical imbalances also occur, with excesses in Western Europe and North America and deficiencies in regions with highly weathered soils, such as sub-Saharan Africa. There is a strong link between soil P stores and $\mathrm{P}$ mobilization and transfer to receiving waters, termed the $\mathrm{P}$ transfer continuum (Haygarth et al., 2005). Ensuring adequate $\mathrm{P}$ for crop production while minimizing water quality degradation requires consideration of this continuum and an international, interdisciplinary approach. This research topic brings together $\mathrm{P}$ studies in soil science, lakes, rivers, estuaries, and oceans, with 74 authors from 12 countries in Asia, Europe, and North America, and identifies key priorities for future research.

In all ecosystems, $\mathrm{P}$ exists in many chemical forms. Inorganic $\mathrm{P}$ compounds include phosphate, pyrophosphate, and polyphosphate, with organisms directly using phosphate $\left(\mathrm{H}_{2} \mathrm{PO}_{4}^{-}\right.$or $\mathrm{HPO}_{4}^{2-}$ at the $\mathrm{pH}$ range of most natural ecosystems). Organic $\mathrm{P}$ compounds contain a link to carbon (C), and include orthophosphate monoesters [e.g., glucose 6-phosphate and myo-inositol hexakisphosphate (myo-IHP or phytate)]; orthophosphate diesters (e.g., nucleic acids, phospholipids); phosphonates (e.g., aminoethyl phosphonate), and biological polyphosphates (e.g., ATP). In all environments, P cycles geochemically and biologically. Geochemical processes include adsorption/desorption of organic and inorganic $\mathrm{P}$ compounds with mineral particles, and precipitation with cations in solution. In biological cycling, phosphate is taken up by organisms and converted to organic $\mathrm{P}$ forms such as nucleic acids or is stored in cells as phytate or polyphosphate. This $\mathrm{P}$ can be released by secretion or after cell death, and converted back to phosphate by mineralization, primarily an enzymatic process involving P-specific enzymes (phosphatases). For more information on $\mathrm{P}$ cycling, a number of review papers are available (e.g., Condron et al., 2005; Pierzynski et al., 2005; Paytan and McLaughlin, 2007; Baldwin, 2013; Karl, 2014; Orihel et al., 2017).

There are similarities and differences in $\mathrm{P}$ cycling in terrestrial and aquatic ecosystems. Terrestrial organisms obtain phosphate from the pool that is dissolved in the soil solution, in the space between the solid components of soil (minerals and organic matter). Here, $\mathrm{P}$ availability is limited by moisture. Easily-obtained (labile) phosphate is taken up from the soil solution, then replenished by desorption, dissolution, or mineralization. 
Because terrestrial plants are fixed in place, strategies have evolved to improve their $\mathrm{P}$ acquisition. This includes changes in rooting structure or associations with rhizosphere microbes and symbionts, which can enhance access to phosphate, or production of phosphatases or organic acids to desorb $\mathrm{P}$ compounds from mineral surfaces (Richardson et al., 2011). Aquatic environments include sediments, benthic biofilms, and the water column. In sediments, organic and inorganic $\mathrm{P}$ compounds will be associated with mineral particles, algal and bacterial biomass (particularly at the sediment-water interface) and organic matter, or occur in aqueous form in pore water. Phosphate and other $\mathrm{P}$ forms can exchange with the water column through adsorption/desorption and precipitation/dissolution, and through uptake and remineralization by organisms in the sediment and in the water column. Within the water column, organic and inorganic $\mathrm{P}$ compounds can be dissolved, associated with colloids, or associated with larger particulates including plankton (e.g., Paytan and McLaughlin, 2007; Orihel et al., 2017; Taylor and Lean, 2018).

Although it can be the most limiting nutrient, or second to nitrogen $(\mathrm{N})$ in many environments, $\mathrm{P}$ cycling in terrestrial and aquatic ecosystems in still poorly understood relative to $\mathrm{C}$ or $\mathrm{N}$, because $\mathrm{P}$ concentrations are orders of magnitude lower than those of $\mathrm{C}$ and $\mathrm{N}$, and due to methodological limitations. Unlike $\mathrm{C}$ and $\mathrm{N}, \mathrm{P}$ has no significant natural gaseous forms, and only one stable isotope $\left({ }^{31} \mathrm{P}\right)$, which can hamper tracing $\mathrm{P}$ sources in the environment, but it does have two radioisotopes $\left({ }^{32} \mathrm{P}\right.$ and $\left.{ }^{33} \mathrm{P}\right)$ that occur naturally or can be added as tracers. Total $\mathrm{P}$ is determined by digestion of solids, or by inductively coupled argon plasma optical emission spectroscopy (ICP-OES) of liquids, and phosphate concentrations in liquids or extracted samples are analyzed by colorimetric techniques such as the molybdate blue method (Murphy and Riley, 1962). However, characterization of specific $\mathrm{P}$ compounds requires advanced techniques such as ${ }^{31} \mathrm{P}$-nuclear magnetic resonance (P-NMR) spectroscopy or P-X-ray Absorption Near Edge Structure (PXANES) spectroscopy that are not readily available to all researchers. Information about biological $\mathrm{P}$ cycling is also limited, particularly the roles of specific organisms. The links between the $\mathrm{P}$ cycle and those of other elements, including $\mathrm{C}$ and $\mathrm{N}$, are also poorly understood.

The papers assembled here provide important new information to address knowledge gaps, and cover all aspects of the soil-freshwater-ocean continuum. Liu et al. examined $\mathrm{P}$ cycling in agricultural lands in Canada. Bol et al. and Reid et al. addressed $\mathrm{P}$ transfer from agricultural land to water,

\section{REFERENCES}

Baldwin, D. S. (2013). Organic phosphorus in the aquatic environment. Environ. Chem. 10, 439-454. doi: 10.1071/EN13151

Condron, L. M., Turner, B. L., and Cade-Menun, B. J. (2005). "Chemistry and dynamics of soil organic phosphorus," in Phosphorus, Agriculture and the Environment, eds J. T. Sims and A. N. Sharpley (Madison, WI: American Society of Agronomy), 87-121. with Reid et al. assessing the components of $\mathrm{P}$ loss and assessment tools, and Bol et al. discussing the need for more integrated research efforts into the processes and mechanisms controlling $\mathrm{P}$ loss. In aquatic environments, $\mathrm{P}$ cycling in lakes was investigated by Thompson and Cotner; Anderson; and Depew et al; in estuaries by Watson et al.; in rivers by Felgentreu et al. and Gomes et al. and in oceans by Björkman et al.; Diaz et al. and Djaoudi et al. Across disciplines, several themes emerged. With respect to methods, colorimetric techniques were frequently used. However, Felgentreu et al. assessed filtration and colorimetric methods in river samples to improve routine monitoring programs, while Djaoudi et al. used techniques to improve the sensitivity of the Murphy and Riley (1962) colorimetric technique to determine nanomolar concentrations of dissolved inorganic P in the Mediterranean Sea. Liu et al. and Watson et al. both used P-NMR to characterize organic $\mathrm{P}$ forms, in soils and estuary sediments respectively, and Liu et al. used P-XANES to characterize soil inorganic $\mathrm{P}$ species. Oxygen isotope ratios of phosphate were used by Depew et al. to identify sources of $\mathrm{P}$ to Lake Erie and pathways of cycling.

Biological $\mathrm{P}$ cycling and $\mathrm{P}$ bioavailability in different ecosystems was a common theme. Liu et al. identified microbial communities in various agricultural soils, showing that soil disturbance controlled $\mathrm{P}$ forms and cycling in these ecosystems. Gomes et al. demonstrated that Amazon and Changjiang river plume phytoplankton communities were shaped by river $\mathrm{N}: \mathrm{P}$ ratios. Björkman et al. assessed spatial variability in the dynamics of inorganic and organic $\mathrm{P}$ compounds in the North Pacific Tropical Gyre with radio tracer techniques, while Diaz et al. estimated the lability of model $\mathrm{P}$ compounds by diatom cultures and used proteomics to examine phosphatase diversity. Anderson measured alkaline phosphomonoesterase activities in freshwater microbial communities, while Thompson and Cotner investigated the bioavailability of dissolved organic $\mathrm{P}$ in lakes in Minnesota and South Dakota; both studies linked P and C biogeochemical cycles.

Thus, the articles in this research topic provide current and interdisciplinary information about $\mathrm{P}$ forms and their cycling along the soil-freshwater-ocean continuum, which is essential for environmentally sustainable P use.

\section{AUTHOR CONTRIBUTIONS}

All authors listed have made a substantial, direct and intellectual contribution to the work, and approved it for publication. 
Karl, D. M. (2014). Microbially mediated transformation of phosphorus in the sea: new views of an old cycle. Ann. Rev. Mar. Sci. 6, 279-335. doi: 10.1146/annurev-marine-010213-135046

Lougheed, T. (2011). Phosphorus paradox: scarcity and overabundance of a key nutrient. Environ. Health. Perspect. 119, A209-A213. doi: 10.1289/ehp.119-a208

Murphy, J., and Riley, J. P. (1962). A modified single solution method for the determination of phosphate in natural water. Anal. Chim. Acta 27, 31-36. doi: 10.1016/S0003-2670(00)88444-5

Orihel, D. M., Baulch, H. M., Casson, N. J., North, R. L., Parsons, C. T., Seckar, D. C. M., et al. (2017). Internal phosphorus loading in Canadian freshwater lakes: a critical review and data analysis. Can. J. Fish. Aquat. Sci. 74, 2005-2029. doi: $10.1139 /$ cjfas-2016-0500

Paytan, A., and McLaughlin, K. (2007). The oceanic phosphorus cycle. Chem. Rev. 107, 563-576. doi: 10.1021/cr0503613

Pierzynski, G. M., McDowell, R. W., and Sims, J. T. (2005). "Chemistry and dynamics of soil organic phosphorus," in Phosphorus, Agriculture and the Environment, eds J. T. Sims and A. N. Sharpley (Madison, WI: American Society of Agronomy), 53-86.

Richardson, A. E., Lynch, J. P., Ryan, P. R., Delhaize, E., Smith, F. A., Smith, S. E., et al. (2011). Plant and microbial strategies to improve the phosphorus efficiency of agriculture. Plant Soil 349, 121-156. doi: 10.1007/s11104-011-0950-4.

Sims, J. T., and Sharpley, A. N. (eds.) (2005). Phosphorus: Agriculture and the Environment. Madison, WI: American Society of Agronomy, 1121.

Taylor, W. D., and Lean, D. R. S. (2018). Observations on the dynamics and fate of dissolved organic phosphorus in lake water and a new model of epilimnetic P cycling. Aquat. Sci. 80:13. doi: 10.1007/s00027-0180564-5

Conflict of Interest Statement: The authors declare that the research was conducted in the absence of any commercial or financial relationships that could be construed as a potential conflict of interest.

Copyright (c) 2019 Duhamel, Dodd, Lønborg, Parsons, Taylor and Her Majesty the Queen in Right of Canada, as represented by the Minister of Agriculture \& Agri-Food Canada. This is an open-access article distributed under the terms of the Creative Commons Attribution License (CC BY). The use, distribution or reproduction in other forums is permitted, provided the original author(s) and the copyright owner(s) are credited and that the original publication in this journal is cited, in accordance with accepted academic practice. No use, distribution or reproduction is permitted which does not comply with these terms. 